\title{
Immune response and biochemistry of calves immunized with rMSP1a (Anaplasma marginale) using carbon nanotubes as carrier molecules
}

\author{
Resposta imunológica e bioquímica de bezerros imunizados com rMSP1a (Anaplasma marginale) \\ utilizando nanotubos de carbono como moléculas carreadoras \\ Bruna Torres Silvestre'; Júlia Angélica Gonçalves da Silveira ${ }^{1 *}$; Elias Jorge Facury-Filho²; \\ Antônio Último de Carvalho²; Alice Freitas Versiani ${ }^{3}$; Letícia Gracielle Tôrres de Miranda Estevam; \\ Márcio Sobreira Silva Araújo ${ }^{4}$; Olindo Assis Martins-Filho ${ }^{4}$; Deborah Aparecida Negrão-Corrêa ${ }^{1}$; \\ Múcio Flávio Barbosa Ribeiro ${ }^{1}$
}

\begin{abstract}
${ }^{1}$ Departamento de Parasitologia, Instituto de Ciências Biológicas - ICB, Universidade Federal de Minas Gerais - UFMG, Belo Horizonte, MG, Brasil

${ }^{2}$ Departamento de Clínica e Cirurgia Veterinárias, Escola de Veterinária, Universidade Federal de Minas Gerais - UFMG, Belo Horizonte, MG, Brasil

${ }^{3}$ Departamento de Microbiologia, Instituto de Ciências Biológicas, Universidade Federal de Minas Gerais - UFMG, Belo Horizonte, MG, Brasil

${ }^{4}$ Laboratório de Biomarcadores de Diagnóstico e Monitoração, Centro de Pesquisas René Rachou, Fundação Oswaldo Cruz - FIOCRUZ, Belo Horizonte, MG, Brasil
\end{abstract}

Received November 16, 2017

Accepted March 23, 2018

\begin{abstract}
Vaccination against Anaplasma marginale has been considered an important control strategy for bovine anaplasmosis. Recently, mice immunized with rMSP1 $a$ linked to carbon nanotubes (MWNT) showed significant immune responses, generating a new possibility for use of an inactivated vaccine. The objective of this study was to investigate the cellular and humoral responses in calves immunized with MWNT+rMSP1 1 , associated with inactivated vaccine of $A$. marginale produced in vitro, and evaluate the toxic effects of the MWNT on renal and hepatic function. rMSP1 $a$ was covalently linked to MWNT. Inactivated vaccine (AmUFMG2) was produced by cultivating $A$. marginale in IDE8 cells. Twenty-four Holstein calves were divided (four groups) and immunized subcutaneously with PBS and non-carboxylated MWNT (control, G1), AmUFMG2 (G2), MWNT+rMSP1a (G3), and AmUFMG2 with MWNT+rMSP1 a (G4). Blood samples were collected for total leukocyte counts, biochemical profiling and evaluation of the cellular and humoral response. Immunization with MWNT+rMSP1 $a$ induced increase in the total number of leukocytes, NK cells, in the lymphocyte populations and higher levels of antibodies compared to calves immunized only with AmUFMG2. Furthermore, MWNT did not induce changes in the biochemical profile. These data indicate that MWNT+rMSP1 $a$ were able to induce the immune responses more efficiently than AmUFMG2 alone, without generating toxicity.
\end{abstract}

Keywords: Anaplasma marginale, MSP1a, inactivated vaccine, carbon nanotubes.

\section{Resumo}

Vacinação contra Anaplasma marginale tem sido considerada uma importante estratégia de controle da anaplasmose bovina. Recentemente, camundongos imunizados com rMSP1a funcionalizada à nanotubos de carbono (MWNT) apresentaram resposta imune significante, gerando nova possibilidade para o uso da vacina inativada. O objetivo desse estudo foi investigar a resposta celular e humoral em bezerros imunizados com MWNT+rMSP1 1 , associado com a vacina inativada de $A$. marginale produzida in vitro, e avaliar os efeitos tóxicos dos MWNT nas funçôes hepática e renal. rMSP1a foi ligada covalentemente aos MWNT. Vacina inativada (AmUFMG2) foi produzida através do cultivo de $A$. marginale em células IDE8. Vinte e quatro bezerros Holandeses foram divididos (quatro grupos) e imunizados subcutaneamente

*Corresponding author: Júlia Angélica Gonçalves da Silveira. Departamento de Parasitologia, Instituto de Ciências Biológicas - ICB, Universidade Federal de Minas Gerais - UFMG, Av. Presidente Antônio Carlos, 6627, Pampulha, CEP 31270-901, Belo Horizonte, MG, Brasil. e-mail: juliaags@yahoo.com.br com: PBS e MWNT não-carboxilados (controle, G1), AmUFMG2 (G2), MWNT+rMSP1 $a$ (G3), e AmUFMG2 com MWNT+rMSP1a (G4). Amostras de sangue foram 
coletadas para contagem de leucócitos, perfil bioquímico e avaliação da resposta celular e humoral. Imunização com MWNT+rMSP1a induziu aumento dos leucócitos totais, células NK, na população de linfócitos e altos níveis de anticorpos comparado com animais imunizados apenas com AmUFMG2. Além disso, MWNT não induziu alterações no perfil bioquímico. Esses dados indicam que MWNT+rMSP1a foram capazes de induzir eficientemente a resposta imune comparado com AmUFMG2 sozinho, sem gerar toxicidade.

Palavras-chave: Anaplasma marginale, MSP1a, vacina inativada, nanotubos de carbono.

\section{Introduction}

Anaplasma marginale is an obligate intraerythrocytic rickettsia (Rickettsiales: Anaplasmataceae) that affects cattle in tropical and subtropical regions, causing severe global economic losses (KOCAN et al., 2010). Various strategies have been attempted to develop a vaccine to reduce the impact of bovine anaplasmosis (AUBRY \& GEALE, 2011).

Inoculation of blood containing a live and less virulent strain of $A$. centrale is the vaccine of choice in many parts of the world (KOCAN et al., 2003). Disadvantages include restricted use in young animals and the high risk of transmitting other blood-borne organisms (RODRÍGUEZ et al., 2000). Moreover, reported outbreaks indicated that this method confers only partial protection against virulent strains of $A$. marginale (BELL-SAKYI et al., 2015).

Inactivated vaccines from $A$. marginale were developed to protect adult bovines against clinical disease. However, they were withdrawn due to the difficulty in purifying rickettsia, maintenance of $A$. marginale-free calves for antigen production, the need for frequent booster applications and the production of isoantibodies in newborn calves of vaccinated dams (KOCAN et al., 2000; RODRÍGUEZ et al., 2000). Establishment of $A$. marginale growth in embryonic cells from the Ixodes scapularis tick (IDE8) was considered a promising alternative in the production of inactivated vaccine. However, this vaccine failed to fully protect adult cattle from clinical disease (GARCIA-GARCIA et al., 2004; LASMAR et al., 2012). One possible reason for the failure could be related to the absence of the Major Surface Protein 1a (MSP1a) expression in this system, due to down-regulation of the mspla gene in $A$. marginale derived from cultured tick cells (GARCIA-GARCIA et al., 2004). Therefore, efforts towards the development of a new generation of vaccines are warranted to protect adult animals from the clinical disease.

Genomic sequencing and bioinformatics tools have provided a comprehensive set of surface proteins of $A$. marginale and therefore potential targets for vaccine development. Among them, MSP1 1 plays an important role in the infection by $A$. marginale, being associated with the adhesion capacity of rickettsia to the bovine erythrocytes and tick cells (GARCIA-GARCIA et al., 2004), and it has been shown to trigger a protective immune response (BROWN et al., 1998, 2001). Recent studies using recombinant MSP1a (rMSP1a) in immunization trials of cattle and laboratory animal models demonstrated an induction of humoral and cellular immune responses associated with an upregulation of pro-inflammatory cytokines (SANTOS et al., 2013; SILVESTRE et al., 2014), suggesting the possibility of its usage in immunization protocols.

Immunization experiments with recombinant proteins are complex due to the many variables that may influence the result, such as the particulate size of the antigen, a potential lack of immunogenic structure of the protein and the route/dose of challenge (NOH et al., 2013). Carrier systems are an alternative method to increase the efficiency of distribution and the presentation of the antigen to the immune system; among them, carbon nanotubes have been widely used as novel delivery agents for drugs, antigens and genes (FOLDVARI \& BAGONLURI, 2008; BIANCO et al., 2011). Recently, we used multi-walled carbon nanotubes (MWNT) as a carrier molecule for the rMSP1a from $A$. marginale strain UFMG2 and found that mice produced a significant humoral and cellular response (SILVESTRE et al., 2014). Thus, the aim of the present study was to investigate the cellular and humoral responses elicited in calves immunized with rMSP1 $a$, using MWNT as a carrier molecule, associated with the inactivated vaccine of $A$. marginale produced in vitro. In addition, the toxic effects of the vaccinations with MWNT were evaluated on renal and hepatic function.

\section{Materials and Methods}

\section{Production of multi-walled carbon nanotubes functionalized to the rMSP1a (MWNT+rMSP1a)}

The rMSP1 $a$ used in this study consists of the $\mathrm{N}$-terminal repeat of the protein and belongs to the $A$. marginale strain UFMG2 (GenBank EU676175.1). Expression and purification steps of the rMSP1 $a$ were performed as described (SILVESTRE et al., 2014).

MWNTs (500 nm in length and $40 \mathrm{~nm}$ in diameter) were solubilized in nitric acid $\left(\mathrm{HNO}_{3}\right.$ ) (ROSCA et al., 2005), and the rMSP1 $a$ immobilization on MWNTs was performed at a 1:3 ratio (v/v) (SILVESTRE et al., 2014). The MWNT+rMSP1a was produced one day before immunization and stored at $4{ }^{\circ} \mathrm{C}$.

\section{Inactivated vaccine of $A$. marginale produced in vitro (AmUFMG2)}

The production of crude antigen was performed by cultivating A. marginale (UFMG2) in IDE8 cells (BASTOS et al., 2009). Initial bodies produced in vitro were purified (LASMAR et al., 2012); thereafter, the sample was sonicated (Ultrasonic Homogenizer 4710, Cole Parmer $\left.{ }^{\circledR}\right)$, and an aliquot was used for protein quantification (BRADFORD, 1976). The remaining sample was stored at $-20^{\circ} \mathrm{C}$.

\section{Experimental animals and immunization}

Twenty-four Holstein calves, 120-130 days of age, free of A. marginale, Babesia bovis and B. bigemina (confirmed by nPCR), were maintained in a tie stall barn and fed with powdered milk, commercial feed and water ad libitum. Calves were kept free of ticks and biting flies by weekly applications of cypermethrin (Flytick ${ }^{\circledR}$, Vallée). 
Calves were randomly divided into four groups with six animals and immunized as shown in the Table 1: calves from the first group (G1 - control group) were immunized with PBS and non-carboxylated MWNTs $(66 \mu \mathrm{g} / \mathrm{calf})$; calves from group 2 (G2) were immunized with AmUFMG2 (400 $\mu \mathrm{g} / \mathrm{calf})$; animals from the group 3 (G3) were immunized with MWNT+rMSP1a $(200 \mu \mathrm{g} / \mathrm{calf})$; and animals from group 4 (G4) were immunized with AmUFMG2 (400 $\mu \mathrm{g} / \mathrm{calf})$ and MWNT+rMSP1a $(200 \mu \mathrm{g} / \mathrm{calf})$. The inoculations were emulsified in oil adjuvant (Emulsigen ${ }^{\circledR}$, USA) and administered subcutaneously at days 0, 21 and 42 .

Throughout the experimental period, all calves were evaluated and monitored daily by clinical examination, including body temperature, heart and respiratory rates and potential adverse reactions in the site of the inoculation. Blood samples were collected in EDTA tubes on days 0 (pre immunization), 42 and 63 for evaluation of the cellular response and on days 0, 21, 42 and 63 for total leukocyte counts, biochemical profiling, and humoral response. Absence of infection by $A$. marginale was confirmed by nPCR (SILVEIRA et al., 2013). All experimental procedures were approved by the Ethics Committee on Animal Use of the Federal University of Minas Gerais (CEUA/UFMG, $\mathrm{n}^{\circ}$ protocol 351/2013).

\section{Immunophenotyping of peripheral lymphocytes}

Blood was collected on days 0,42 and 63 in tube $(4 \mathrm{~mL}$, EDTA), and after 2 to 3 hours, the immunophenotyping protocol was performed as follows: aliquots of $40 \mu$ of whole blood were incubated with the following monoclonal bovine-specific antibodies: anti-CD4 (clone CC8, 1:10 dilution), anti-CD8 (clone CC63, 1:10), anti-CD21 (clone CC21, 1:5 - B cells, NAESSENS et al., 1990) associated with anti-CD335 (clone AKS1, 1:10 - bovine natural killer cells, STORSET et al., 2004), or anti-CD25 (clone IL-A111, 1:10 - activated T lymphocytes, MAŚLANKA \& JAROSZEWSKI, 2012) and isotype control (Mouse IgG2a, 1:10 - Negative Control Antibody, MCA929F) conjugated with FITC (fluorescein isothiocyanate) or PE (phycoerythrin), purchased from AbD Serotec ${ }^{\circledR}$ (Bio-Rad, USA). Phenotypic labelling of leukocytes was performed as described (DORNELES et al., 2015). The cells were collected by FACScan flow cytometry (Becton Dickinson, USA) with gate selection for the lymphocyte population and acquisition of 30,000 events. Phenotypic analysis was performed using the FlowJo 7.6.1 software (Tree Star, USA). To be converted into absolute values, the percentage data obtained by cytometry were combined with leukogram data from each animal. Leukocyte counts were performed in a Neubauer chamber, using Thomas

Table 1. Immunization protocol of the calves.

\begin{tabular}{cc}
\hline Group & Immunogen \\
\hline G1 & PBS + non-carboxylated MWNTs $(66 \mu \mathrm{g} /$ calf $)-$ Control \\
& group \\
G2 & AmUFMG2 $(400 \mu \mathrm{g} / \mathrm{calf})$ \\
G3 & MWNT+rMSP1 $a(200 \mu \mathrm{g} / \mathrm{calf})$ \\
G4 & AmUFMG2 $(400 \mu \mathrm{g} / \mathrm{calf})$ and MWNT+rMSP1 $a$ \\
& $(200 \mu \mathrm{g} /$ calf $)$ \\
\hline
\end{tabular}

fluid as the diluent, and expressed in thousands of cell/ $\mu \mathrm{l}$ of blood (BENESI et al., 2012).

\section{Evaluation of $\operatorname{Ig} G, \operatorname{Ig} G 1$ and $\operatorname{Ig} G 2$ antibodies levels}

Evaluation of anti-rMSP $1 a$ and anti- $A$. marginale IgG, IgG1 and IgG2 antibodies was performed by ELISA, as described (SILVESTRE et al., 2014). The rMSP1 $a$ protein and the antigen of $A$. marginale UFMG2 produced in vitro used for immunization of calves were also utilized as antigens for the assay $(0.1 \mu \mathrm{g} /$ well - IgG or $0.5 \mu \mathrm{g} /$ well - IgG1/IgG2).

Plasma samples $(100 \mu \mathrm{l} /$ well $)$ obtained at days $0,21,42$ and 63 were diluted to 1:2000 (IgG) or 1:400 (IgG1 and IgG2). Horseradish peroxidase-conjugated anti-bovine antibodies were diluted to 1:40000 (IgG, Sigma $\left.^{\circledR}\right)$ or 1:2000 (IgG1, BioRad ${ }^{\circledR} ; \operatorname{IgG} 2$, Sigma $\left.^{\circledR}\right)$. The $\mathrm{OD}_{450}$ was measured in a microplate reader (Epoch Microplate Spectrophotometer, Biotek ${ }^{\circledR}$ ), and the data obtained were plotted onto bar graphs.

\section{Biochemical profile}

Plasma and serum samples obtained on days 0 (pre immunization), 21, 42 and 63 were used to evaluate the renal and hepatic function of the calves to verify the impact of the immunization with carbon nanotubes on animal health. Serological biochemical parameters including glucose, creatinine, albumin, alkaline phosphatase (ALP), total protein, gamma-glutamyl transferase (GGT), alanine transaminase (ALT) and aspartate transaminase (AST) were evaluated using Cobas Mira Plus (Roche Diagnostic Systems ${ }^{\circledR}$ ) and diagnostic kits manufactured by Kovalent (Biosys ${ }^{\circledR}$, Brazil), following the manufacturer's instructions.

\section{Statistical analysis}

Lilliefors test was used to determine the normality of the data. For analyses among groups at each time point, we used the Kruskal-Wallis test, followed by Dunn's test. Friedman test was performed to assess the existence of differences between the time points in each group (SAMPAIO, 2010). Statistical analysis was performed using the software InfoStat ${ }^{\circledR}$ (version 2008), and median values were considered statistically significant at $\mathrm{P}$-value $<0.05$. For detection of potential outliers, the data were subjected to the Graphpad QuickCalcs Outlier Calculator (GraphPad Software, 2017).

\section{Results}

\section{Immunization of calves with MWNT+rMSP1a induced an increase in the cellular response}

In order to evaluate the cellular response stimulated during and after the immunizations, blood samples were collected of the all experimental groups: G1- control group (immunized with PBS and non-carboxylated MWNTs), G2 (immunized only with AmUFMG2), G3 (only with MWNT+rMSP1a) and G4 (AmUFMG2 associated with MWNT+rMSP1a). Our data 
showed that calves from the control group (G1) presented no change in the total number of circulating leukocytes during the experiment (Figure 1). In contrast, on day 42, calves from the G4 showed significantly higher values of leucocytes compared to the G1, G2 and G3 groups $(\mathrm{p}<0.05)$. In the same period (day 42), calves from G2 showed a significant decrease in these cells compared to values obtained on day 21 in the same group. At day 63, the total leukocyte counts of the G2, G3 and G4 were considered statistically higher compared to the control group (G1) $(p<0.05)$. Calves from the G2 and G3 were statistically higher when compared to the G4 group at day $63(\mathrm{p}<0.05)$.

No significant difference was observed in the number of circulating CD $335^{+}$cells (NK cells - Figure 2) in the G1 and G4 throughout the experiment $(\mathrm{p}>0.05)$. At day 42 , calves from the G2 showed a significant decrease of these cells compared to values observed on day $0(\mathrm{p}<0.05)$. Animals immunized with MWNT+rMSP1a (G3) had a significant increase in the number of circulating $\mathrm{CD}_{3} 35^{+}$cells at day 63 compared to day 0 of the same experimental group, and this increase was considered significantly higher compared to all the other experimental groups $(\mathrm{p}<0.05)$ (Figure 2).

The kinetics of circulating lymphocyte populations after the different immunization protocols is illustrated in Figure 3. Similarly, the number of circulating $\mathrm{CD}^{+}{ }^{+} \mathrm{T}$ cells in the $\mathrm{G} 1$ showed no significant differences among all of the evaluated days, while animals from the G2 showed a significant reduction after the second immunization (day 42), followed by a significant increase of these cells at day $63(\mathrm{p}<0.05)$ (Figure 3a). At day 42, calves from the G3 and G4, which received the MWNT+rMSP1 $a$, showed statistically higher numbers of $\mathrm{CD}^{+} \mathrm{T}$ cells when compared to the G2 ( $\mathrm{p}<0.05)$. After the third immunization (day 63), only the G3 group was considered higher than the control group (G1) $(\mathrm{p}<0.05)$ (Figure 3a).

Regarding of the circulating $\mathrm{CD}^{+} \mathrm{T}$ lymphocytes, calves from G1, G2 or G3 showed an increase of this marker at day 63 compared to day 0 for the same experimental group $(\mathrm{p}<0.05)$

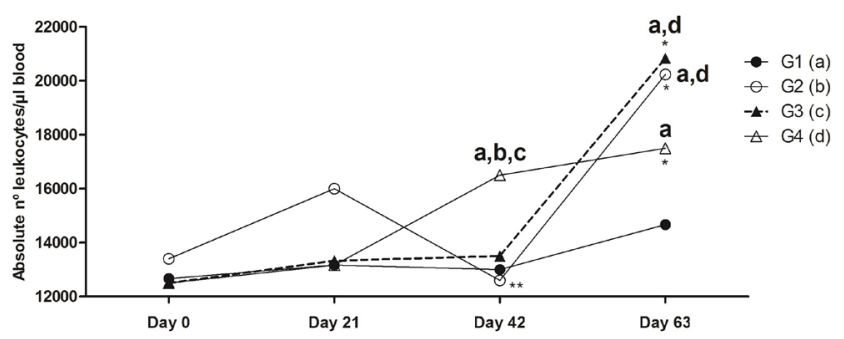

Figure 1. Median values of leukocyte counts at days 0 (pre-immunization), 21, 42 and 63. $\left(^{*}\right)$ Represents statistically significant differences within each group compared to day $\left.0(\mathrm{p}<0.05) ;{ }^{* *}\right)$ Statistically significant difference within group G2 compared to day 21, according to the Friedman test $(p<0.05)$. Letters represent statistically significant differences among groups according to the Kruskal-Wallis test $(\mathrm{p}<0.05):(\mathrm{a})=$ represent statistically significant difference in relation to the control group - G1; (b) = statistically significant difference in relation to the G2 group - AmUFMG2; (c) = in relation to the G3 group - MWNT+rMSP1 $a$; $(\mathrm{d})=$ in relation to the G4 group - AmUFMG2 associated with MWNT+rMSP1a $(\mathrm{n}=6)$.
(Figure 3b). Calves from G4 showed no significant variations throughout the experiment ( $p>0.05)$. To determine the existence of significant differences among the immunization protocols, the values obtained in each group were compared with each other at each point time. At day 63, calves from G3 showed a significant increase in the number of $\mathrm{CD}^{+} \mathrm{T}$ lymphocytes circulating compared with G1, G2 and G4 ( $\mathrm{p}<0.05)$ (Figure 3b).

Animals from G2 and G3 showed a significant increase in the absolute number of $\mathrm{B}$ cells after the third immunization (day 63) compared to day 0 ( $\mathrm{p}<0.05$ ) (Figure 3c). In calves from $\mathrm{G} 4$, this increase was observed earlier, starting from the second immunization (day 42) (Figure 3c). On this day, the number of B cells circulating observed in the G4 group was statistically higher to calves from G1 and G2 ( $<<0.05)$. On the other hand, at day 63, the median values for G3 were statistically higher than G2 and G4 ( $<<0.05)$.

Only the animals that received MWNT+rMSP1 $a(\mathrm{G} 3)$ showed a significant increase of activated $\mathrm{T}$ lymphocytes $\left(\mathrm{CD} 25^{+}\right)$between the second and third doses (days 42 and 63, respectively) $(\mathrm{p}<0.05)$ (Figure 3d). Furthermore, the increase of this marker observed in the calves from the G3 after the third dose (day 63) was considered significant when compared to the other groups $(\mathrm{p}<0.05)$.

\section{$M W N T+r M S P 1 a$ induced high levels of IgG, IgG1 and IgG2 antibodies}

To evaluate the effect of different vaccination protocols on the levels of antibodies produced, plasma samples were used to detect IgG, IgG1 and IgG2 anti-rMSP1 $a$ and anti- $A$. marginale. As observed in Figure 4, the G1 did not produce antibodies against rMSP $1 a$ or the crude extract of $A$. marginale throughout the experiment. Moreover, calves that received only the rMSP1a (G3) did not respond to the antigen of inactivated vaccine (Figure 4d-f), and animals that received only inactivated vaccine (G2) did not recognize the rMSP1 $a$ protein (Figure 4a-c).

Figure 4a shows the median absorbance values of $\operatorname{IgG}$ anti-rMSP $1 a$ obtained in each experimental time for each group. After the second and third immunizations (days 42 and 63, respectively), both G3 and G4 presented statistically higher levels of this antibody compared to animals from G1 and G2 ( $<<0.05)$. However, at day 63, the levels of IgG anti-rMSP1a found in G3 were statistically higher than those observed in calves from G4 $(\mathrm{p}<0.05)$. Furthermore, we observed that levels of IgG anti-rMSP $1 a$ in calves from G4 showed no increase between the second (day 42) and third immunization (day 63) as observed in G3 (Figure 4a).

Analyses of IgG1 anti-rMSP $1 a$ revealed that absorbance values were statistically higher in G3 compared to the control group as early as 21 days after the first immunization, while those in G4 showed an increase only after the second immunization (day 42) $(\mathrm{p}<0.05)$. No significant differences were detected between G3 and G4 regarding the levels of IgG1 anti-rMSP $1 a$ at all time points analysed (Figure 4b).

Regarding IgG2 anti-rMSP $1 a$, calves from G3 and G4 showed statistically higher levels of this antibody from day 21 onwards compared to G1 ( $<<0.05)$ (Figure 4c). Expectedly, levels of IgG2 anti-rMSP1 $a$ in G3 were statistically higher than in G2 from the 
A
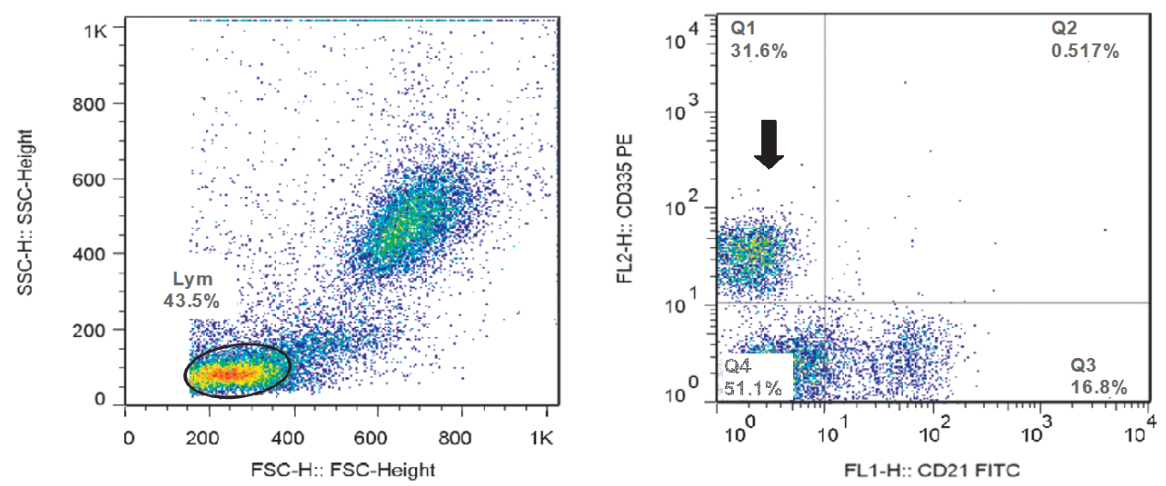

B

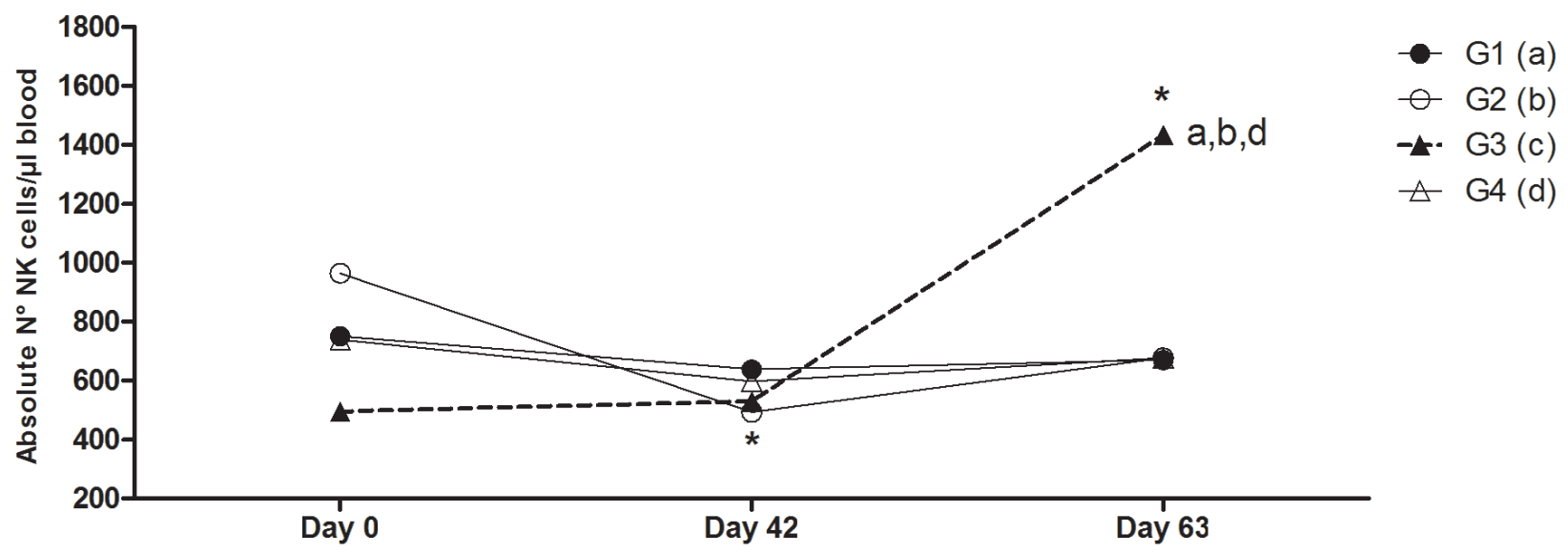

Figure 2. (A) Lymphocytes were identified based on their size and granularity using flow cytometry. Analysis of CD335+ (NK cells) was performed within the selected lymphocyte region based on the relative fluorescence intensity observed in FL1 versus FL2 dot plot distributions

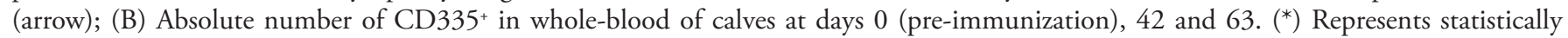
significant differences within each group compared to day 0 , according to the Friedman test $(\mathrm{p}<0.05)$. Letters represent statistically significant differences among groups according to the Kruskal-Wallis test $(\mathrm{p}<0.05)$ : (a) = represent statistically significant difference in relation to the control group - G1; (b) = statistically significant difference in relation to the G2 group - AmUFMG2; (c) = in relation to the G3 group - MWNT+rMSP1 ; (d) = in relation to the G4 group - AmUFMG2 associated with MWNT+rMSP1a (n=6).

first immunization onwards (day 21) $(\mathrm{p}<0.05)$. In contrast, calves from G4 were considered statistically superior to G2 only on day 42 of the experiment $(\mathrm{p}<0.05)$. No significant differences were detected regarding the levels of IgG2 anti-rMSP1 $a$ between G3 and G4 at all time points.

The median absorbance values of IgG anti- $A$. marginale obtained from each group are illustrated in Figure 4d. From day 21, calves from G4 showed significantly higher levels of this antibody than G1 and G3 (p<0.05). Group G2 showed significantly higher levels of IgG anti- $A$. marginale compared to G3 at day 21 and to G1 from day $42(\mathrm{p}<0.05)$. No significant differences were detected between $\mathrm{G} 2$ and $\mathrm{G} 4$ at all time points.

Analyses of IgG1 anti- $A$. marginale demonstrated a significant increase of this antibody from day 21 in G4 compared to animals from G1 and G3 (p<0.05) (Figure 4e). In G2, this significant increase was observed only from day $42(\mathrm{p}<0.05)$. Figure $4 \mathrm{f}$ shows that from day 21, calves from G2 and G4 presented levels of IgG2 anti- $A$. marginale that were significantly higher than G1 and G3 $(\mathrm{p}<0.05)$. No significant differences were detected regarding the levels of IgG1 and IgG2 anti-A. marginale between G2 and G4 at all time points (Figure 4e-f).

\section{MWNT did not induce changes in the biochemical profile of immunized calves}

Throughout the experimental period, the calves showed no clinical changes, and no evidence of a reaction was observed at the vaccination sites. To evaluate whether the immunization of the calves with MWNT induced renal and hepatic disorders, plasma and serum samples obtained after the immunizations were used for biochemical profile analyses. Comparative analysis among the groups demonstrated that calves that received MWNT 
A
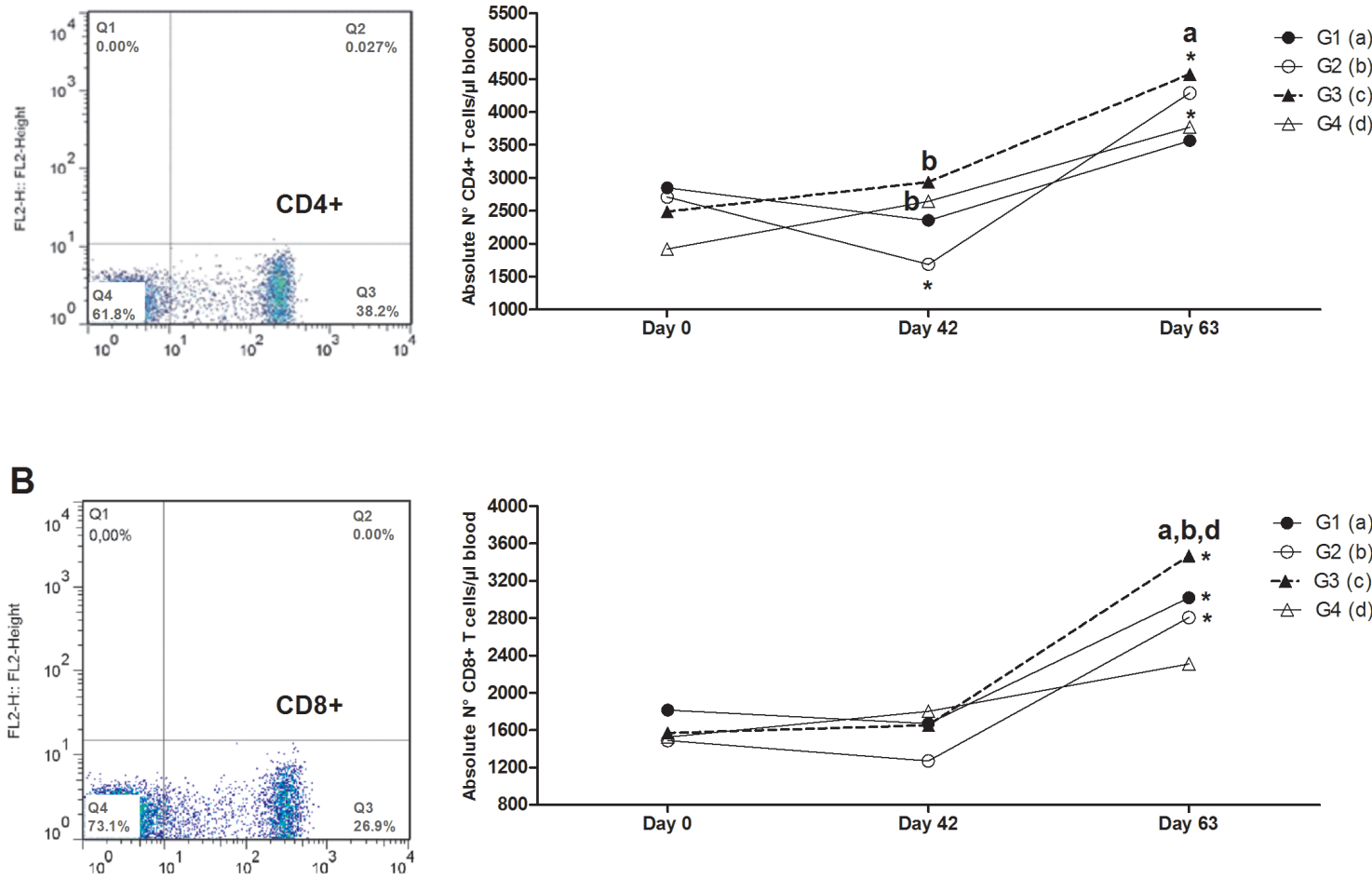

C
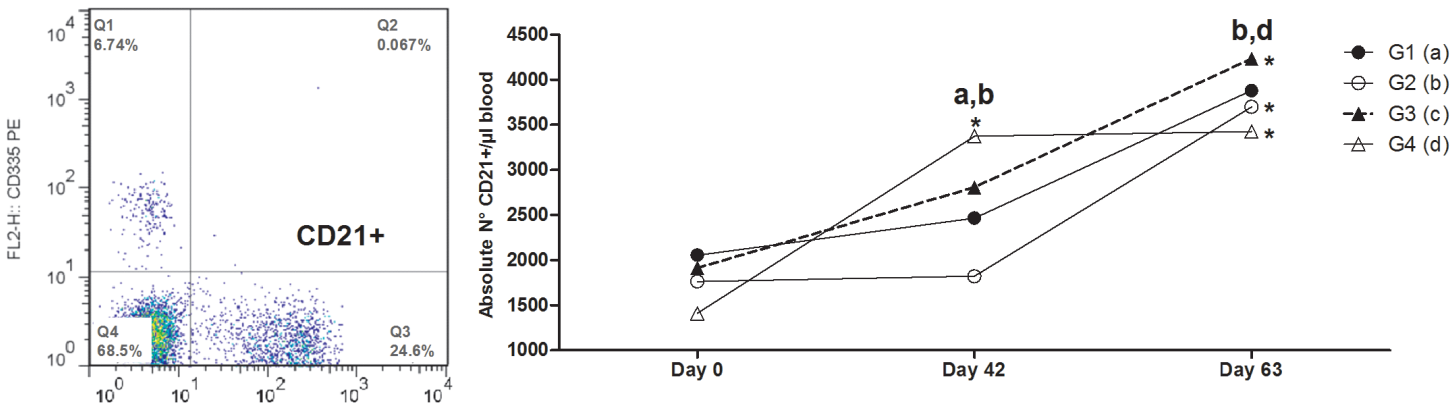

D
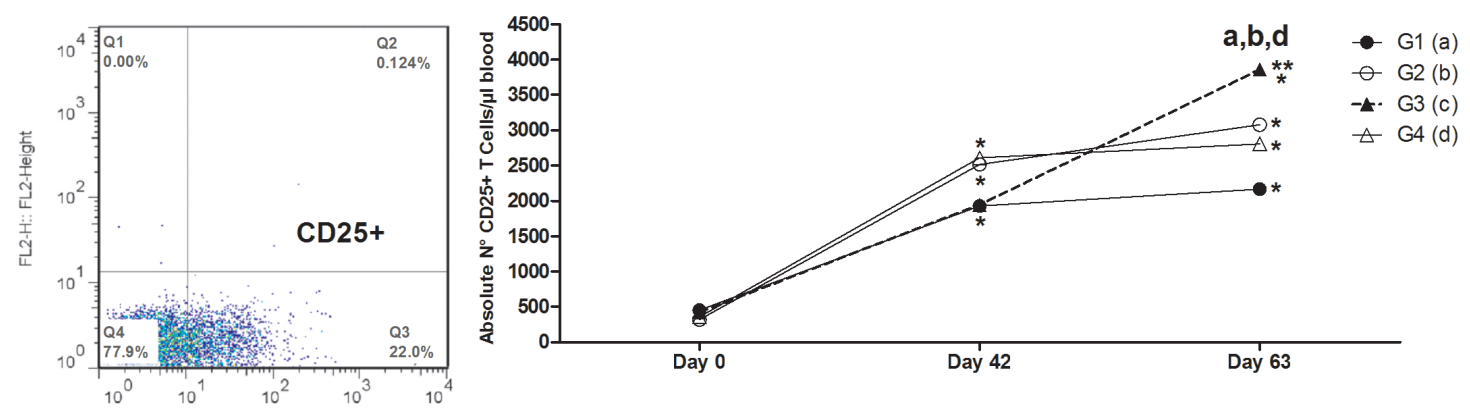

Figure 3. Analysis of the lymphocytes in whole-blood of calves at days 0 (pre-immunization), 42 and 63. (A) Kinetics of the absolute number of CD4+ T lymphocytes; (B) CD8+ T lymphocytes; (C) CD21+ lymphocytes (B cells); and (D) CD25+ T lymphocytes (activated T lymphocytes). $\left(^{*}\right)$ Represent statistically significant differences within each group compared to day $0(\mathrm{p}<0.05)$; $(* *)$ Statistically significant difference within group G3 compared to day 42, according to the Friedman test $(\mathrm{p}<0.05)$. Letters represent statistically significant differences among groups according to the Kruskal-Wallis test $(\mathrm{p}<0.05)$ : $(\mathrm{a})=$ represent statistically significant difference in relation to the control group - G1; (b) = statistically significant difference in relation to the G2 group - AmUFMG2; (c) = in relation to the G3 group - MWNT+rMSP1a; $(\mathrm{d})=$ in relation to the G4 group - AmUFMG2 associated with MWNT+rMSP1a (n=6). 
A

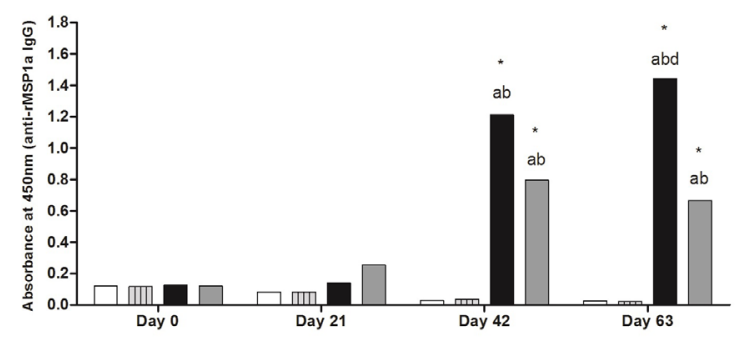

B

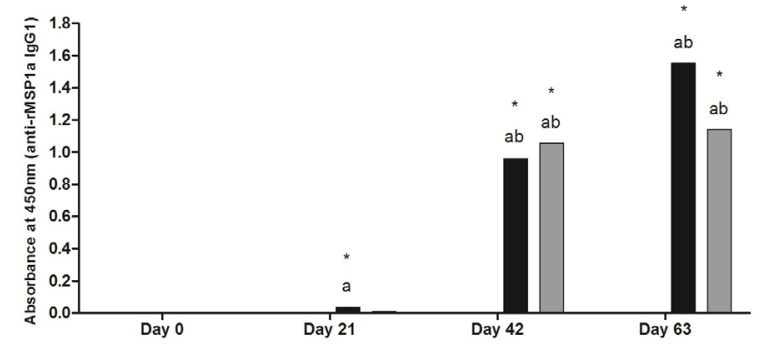

C
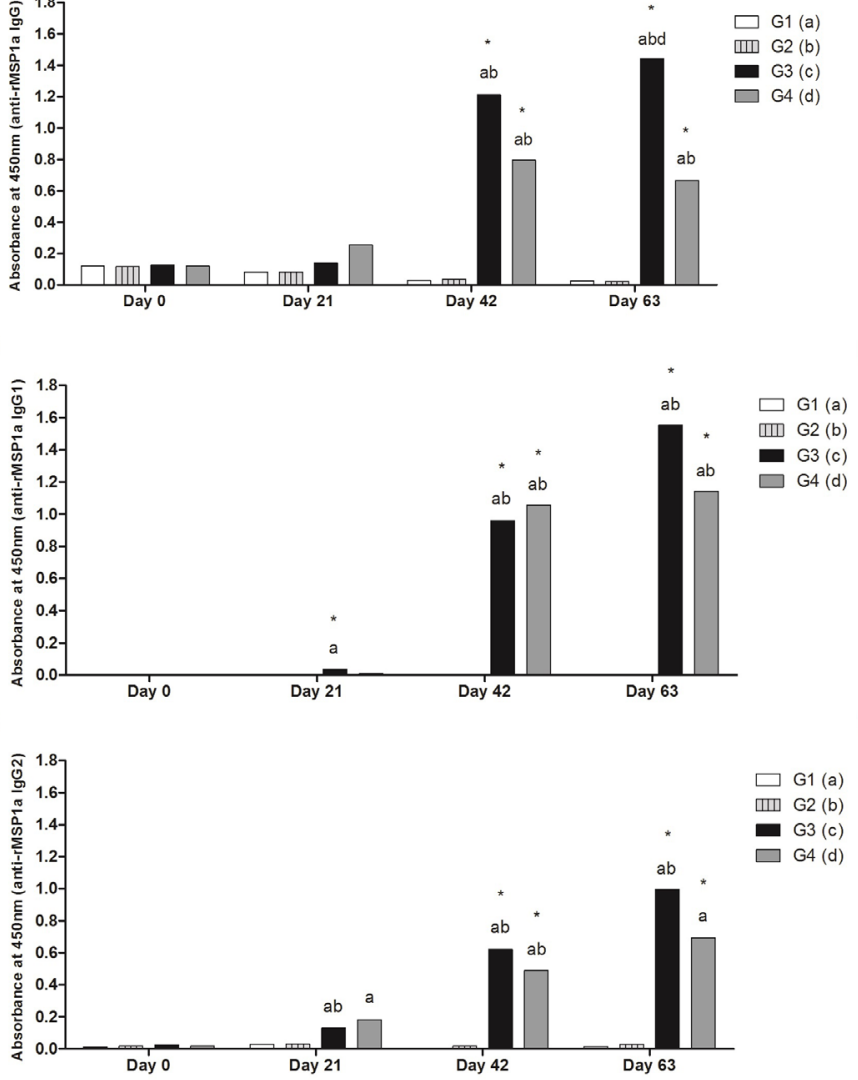

D

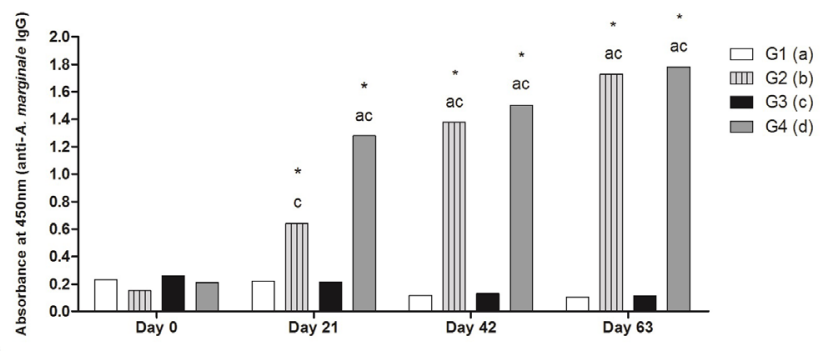

E

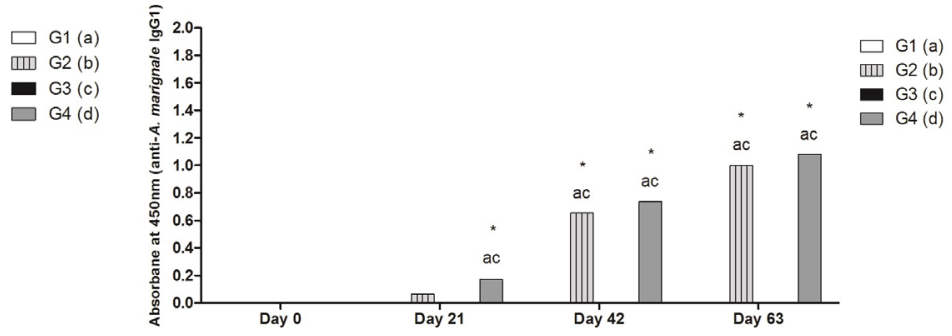

F

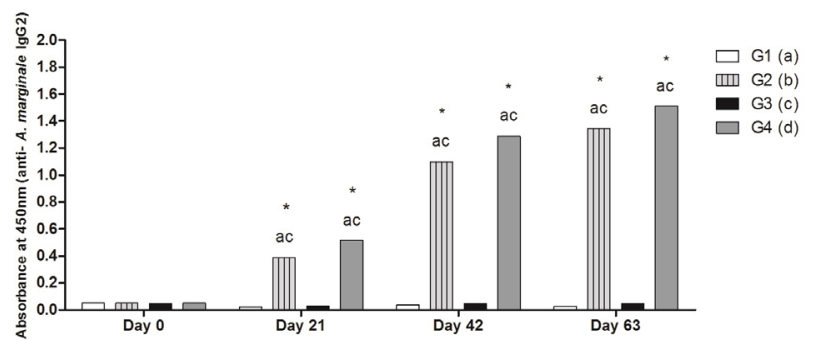

Figure 4. Induction of the humoral response after immunizations. Measurements of antibodies (A) IgG anti-rMSP1 $a$; (B) IgG1 anti-rMSP1 $a$; (C) IgG2 anti-rMSP1a; (D) IgG anti-A. marginale; (E) IgG1 anti- $A$. marginale; and (F) IgG2 anti- $A$. marginale by ELISA. Each bar represents the median value of each group $(\mathrm{n}=6)$. $\left(^{*}\right)$ Represents statistically significant differences within each group compared to day 0 (pre-immunization), according to the Friedman test $(\mathrm{p}<0.05)$. Letters represent statistically significant differences among groups according to the Kruskal-Wallis test $(\mathrm{p}<0.05):(a)=$ represent statistically significant difference in relation to the control group - G1; $(b)=$ statistically significant difference in relation to the G2 group - AmUFMG2; (c) = in relation to the G3 group - MWNT+rMSP1a; (d) = in relation to the G4 group - AmUFMG2 associated with MWNT+rMSP1a $(\mathrm{n}=6)$.

(G1, G3 and G4) did not show a significant change in the biochemical profile compared with animals from G2 that did not receive MWNT ( $>0.05$ ) (Table 2 ). In comparison to the reference values established for cattle, all groups showed higher values of albumin, total protein and GGT at day 63, including calves from the G2 group (MWNT non-immunized) (Table 2).

\section{Discussion}

The development of vaccines is a powerful alternative to control $A$. marginale while reducing the use of pharmaceuticals and their residues in the human food chain (KOCAN et al., 2003). However, it is already known that antigen carrier systems have the ability to efficiently deliver small antigenic molecules (FOLDVARI \& BAGONLURI, 2008), and in this study, we evaluated the cellular and humoral responses elicited in calves immunized with MWNT+rMSP1 $a$ associated with an inactivated vaccine of A. marginale produced in vitro, as well as the toxic effects of the MWNT in the renal and hepatic function of immunized calves.
Immunization with MWNT+rMSP1 $a$ induced changes in the total leukocyte counts, in the number of circulating CD $335^{+}$cells (NK cells) and lymphocyte populations after the third immunization. Number of circulating NK cells was higher in calves that received only MWNT+rMSP1a (G3) than in calves immunized with inactivated vaccine (G2). Although animals from G4 received the same amount of MWNT+rMSP1a, they also received the crude extract of $A$. marginale produced in vitro, which may have interfered in the production of NK cells, as observed in the animals from G2, through an unknown mechanism. NK cells are a component of the innate immune system and provide an initial defence against intracellular bacteria through IFN- $\gamma$ production before the development of acquired immunity mediated by T lymphocytes (BOYSEN \& STORSET, 2009). IFN- $\gamma$ plays an important role in the control of $A$. marginale through the activation of macrophages, which eliminate rickettsia by phagocytosis and nitric oxide production (BROWN, 2012). Activation of NK cells is regulated by MHC I molecules, and infected erythrocytes with A. marginale do not express MHC. However, Chen et al. (2014) 
demonstrated that NK cells play a critical role in the control of the intraerythrocytic parasite Plasmodium falciparum in immune mice. Although the role of NK cells in the infection by A. marginale is not known, the results presented here indicate that immunization with MWNT+rMSP1 $a$ can elicit an increase in the NK cell population.

Calves immunized with MWNT+rMSP1a (G3 and G4) showed significantly increased percentage of the $\mathrm{CD}^{+} \mathrm{T}$ lymphocytes population in comparison to the animals immunized with inactivated vaccine alone (G2). Control of infection and induction of a protective response against $A$. marginale have been shown to require an increase in the population of $\mathrm{CD} 4^{+} \mathrm{T}$ cells. These cells secrete IFN- $\gamma$, which activates macrophages by inducing the cells to produce several antibacterial substances and stimulates the production of neutralizing antibodies by $\mathrm{B}$ cells, which are able to opsonize $A$. marginale and trigger phagocytosis of the pathogen by macrophages (BROWN, 2012).

Analysis of $\mathrm{CD}^{+} \mathrm{T}$ lymphocytes did not reveal statistically significant differences among the groups; however, animals receiving the MWNT+rMSP1 $a$ alone (G3) showed higher levels of this marker at day 63 in comparison to the other groups. Although the role of $\mathrm{CD}^{+} \mathrm{T}$ cells in infection by $A$. marginale is not known (WALKER \& DUMLER, 2015), these cells feature a crucial function in the control and elimination of infection by other rickettsias (WALKER et al., 2001).

Immunization of calves with MWNT+rMSP $1 a$ also induced a significant increase in the number of B cells. After the second immunization, calves from G4 showed a higher number of B cells than calves from the control group (G1) and from calves that received inactivated vaccine $(\mathrm{G} 2)$. In calves that received only MWNT+rMSP1a (G3), this increase was observed after the third immunization compared to G2 and G4. Elimination of different pathogens, such as $A$. marginale, requires the participation of several effector mechanisms, including activation of B cells and secretion of different isotypes of antibodies. IFN- $\gamma$ secreted by A. marginale-stimulated $\mathrm{CD}^{+} \mathrm{T}$ cells is the main molecular propellant to induce $\mathrm{B}$ cells to undergo the heavy chain switching process, which promotes the production of IgG2 (ESTES et al., 1994; KOCAN et al., 2003). IgG2 produced during infection neutralizes the process of erythrocyte invasion or opsonizes rickettsia to be targeted to phagocytosis by macrophages (BROWN, 2012). Sequencing rMSP1a (UFMG2) used in the immunization of calves of the current study showed three linear B cell epitopes (SSSASGQQQ) (SILVESTRE et al., 2014), suggesting that MSP1a-UFMG2 may stimulate the activation of these cells and production of IgG2 antibody.

Expression of $\mathrm{CD}_{2} 5^{+}$marker by $\mathrm{CD} 4^{+} \mathrm{T}$ cells and their consequent activation is crucial for infection control by $A$. marginale (KOCAN et al., 2003). Between the second and third immunizations, calves that received only MWNT+rMSP1a (G3) showed an increase in the number of activated T lymphocytes $\left(\mathrm{CD} 25^{+}\right)$. Recently, we observed that mice immunized with MWNT+rMSP1 $a$ showed an efficient adaptive immune response through an increase in the lympho-proliferative response and high percentage of activated T lymphocytes (SILVESTRE et al., 2014). Taken together, these data suggest that rMSP1 $a$ functionalized with MWNT could efficiently stimulate the adaptive immune response in calves immunized with MWNT+rMSP1a. The efficiency in the use of carbon nanotubes as a carrier molecule of vaccine antigens has also been reported in previous studies, in which a significant cellular response and increase in the production of neutralizing antibodies was observed in animals immunized with the this nanoparticle (PANTAROTTO et al., 2003; YANDAR et al., 2008; ZEINALI et al., 2009).

Throughout the analyses, the G4 group showed a constant increase in all cell markers. Such data are in contrast to the significant reduction observed in the G2 group (which also received the inactivated vaccine), especially in relation to the total leukocyte count and the absolute number of $\mathrm{CD}^{+} \mathrm{T}$ cells. However, the increase observed in G4 was not as robust as in the G3 group, which only received MWTN+rMSP1a. These factors reinforce the presence of immunomodulatory antigens in the inactivated vaccine, which are capable of suppressing the development of the immune response (ABBOTT et al., 2005; TURSE et al., 2014). Calves from the G4 group received a high load of $A$. marginale inactivated antigens ( $400 \mu \mathrm{g} / \mathrm{calves} / \mathrm{dose})$ in addition to MWNT+rMSP1 $a$, which may have contributed to the maintenance of total leukocyte, $\mathrm{CD} 4^{+}, \mathrm{CD}^{+}, \mathrm{CD} 21^{+}$and $\mathrm{CD} 25^{+}$ levels observed between the second and third immunization of this group. This high dose of antigen may have favoured the activation of immunosuppressive mechanisms that, together with the presence of the immunomodulatory antigens in the inactivated vaccine, contributed to the lack of high levels of evaluated markers, as observed in the G3 group. Han et al. (2010) affirmed that the high antigen load observed during infection by $A$. marginale induced a dysfunction of $T$ cells newly activated by immunization, which are characterized by the rapid deletion of $A$. marginale-specific cells. The association of the inactivated vaccine produced in vitro with MWNT+rMSP1a may have contributed to the lack of significant reduction in cell markers evaluated here. However, under the conditions used in the present study, this association was not sufficient to prevent the action of immunomodulatory mechanisms from the inactivated vaccine.

Because it is already known that the protective immunity against $A$. marginale requires the activation of a cell response and the involvement of neutralizing antibodies (BROWN, 2012), a humoral response was assessed in this study. Immunization of calves with MWNT+rMSP1 $a$ induced a strong antibody response of IgG, IgG1 and IgG2 anti-rMSP1 $a$. Although both G3 and G4 received the same amount of $\mathrm{rMSP} 1 a$ during the immunizations, calves that received only MWNT+rMSP1a (G3) showed an IgG anti-rMSP1 $a$ response that was higher compared to animals from G4. Although G3 showed high levels of IgG1 and IgG2 anti-rMSP1a in calves from G4 at day 63, no significant difference was observed between the two groups. However, the maintenance of the levels of antibodies after the second and third doses observed in calves from the G4 group may have contributed to this reduction. In cattle, the production of IgG1 is IL-4-dependent, whereas IFN- $\gamma$ induces the production of IgG2 (ESTES et al., 1994, 1995). Although IFN- $\gamma$ levels were not measured in this study, we observed that calves immunized with only MWNT+rMSP1a (G3) showed an increase in IgG2 anti-rMSP1a levels compared with calves receiving the inactivated vaccine. 
The decrease in the production of IgG, IgG1 and IgG2 anti-rMSP $1 a$ observed in calves from G4 may be related to the presence of immunomodulatory antigens in the inactivated vaccine produced in vitro. This immunomodulation has been reported in previous studies, where $A$. marginale induced the evasion of innate and adaptive immune responses due to the high loading of antigens and the presence of immunomodulatory antigens (BROWN, 2012; TURSE et al., 2014). These results indicated that the immunization of calves with only MWNT+rMSP1 $a$ could induce a humoral response more efficiently than in association with the crude antigen of $A$. marginale.

Carbon nanotubes are promising nanomaterials with great potential in the field of nanomedicine; however, an investigation of their toxicity is needed to determine the potential danger of exposure to nanoparticles (BIANCO et al., 2011). Here, we evaluate the biochemical profile of calves immunized with MWNT to confirm potential renal and hepatic disorders. No significant change in the biochemical profile was observed in calves immunized with MWNT (G1, G3 and G4) compared with animals from the G2 group that did not receive MWNT, suggesting that the concentration of MWNT used in this study did not alter the analysed parameters. Changes observed in the albumin, total protein and GGT levels at day 63 were considered within the limit of normality. This may be associated with several factors, such as weaning and increase in the consumption of concentrated feed (CONTRERAS, 2000; MIRANDA, 2013), dehydration, age and the establishment of an effective ruminal microbiota due to adaptation to the new metabolic status of the calves (KURZ \& WILLETT, 1991). These variations were not related with hepatic disorder symptoms (BOUDA et al., 1980; CONTRERAS, 2000). Thus, analysis of renal and hepatic function is one important parameter for the evaluation of the health of animals subjected to the subsequent vaccinations and can be used to evaluate the toxic effects of vaccinations, dosages and immunization periods (KANEKO et al., 2008).

\section{Conclusions}

The results presented here indicate that the immunization of calves with MWNT+rMSP $1 a$ could induce cellular and humoral responses more efficiently than AmUFMG2 alone, through an increase in total leukocyte counts, in the number of circulating NK cells and lymphocyte populations and in the expression of high levels of $\operatorname{IgG}$, IgG1 and $\operatorname{IgG} 2$ antibodies. Furthermore, no significant change in the biochemical hepatic and renal profile was observed in calves immunized with MWNT, suggesting that MWNT did not induce toxicity. Although the group of animals immunized with MWNT+rMSP1 $a$ associated with AmUFMG2 showed an increase in cell markers, such an increase was not as significant compared to calves immunized with only MWNT+rMSP1a. Therefore, further studies should be performed to define the role of these immunological markers, stimulated by MWNT+rMSP1 $a$, in infectious control and in the immunopathology of bovine anaplasmosis to identify the combination of antigens necessary to protect susceptible animals from clinical disease.

\section{Acknowledgements}

The authors wish to thank UFMG (Universidade Federal de Minas Gerais), CAPES (Coordenação de Aperfeiçoamento de Pessoal de Nível Superior), and Dr. Élida Mara Leite Rabelo and Dr. Flávio G. da Fonseca for their assistance with this study. This manuscript was reviewed by a professional scientific editor and by a native English-speaking copy editor to improve readability. This research did not receive any specific grant from funding agencies in the public, commercial, or not-for-profit sectors.

\section{References}

Abbott JR, Palmer GH, Kegerreis KA, Hetrick P, Howard CJ, Hope JC, et al. Rapid and long-term disappearance of CD4+ T-lymphocyte responses specific for Anaplasma marginale major surface protein-2 (MSP2) in MSP2 vaccinates following challenge with live $A$. marginale. J Immunol 2005; 174(11): 6702-6715. http://dx.doi.org/10.4049/ jimmunol.174.11.6702. PMid:15905510.

Aubry P, Geale DW. A review of bovine anaplasmosis. Transbound Emerg Dis 2011; 58(1): 1-30. http://dx.doi.org/10.1111/j.1865-1682.2010.01173.x. PMid:21040509.

Bastos CV, Passos LFM, Vasconcelos MMC, Ribeiro MFB. In vitro establishment and propagation of a Brazilian strain of Anaplasma marginale with appendage in IDE8 (Ixodes scapularis) cells. Braz J Microbiol 2009; 40(2): 399-403. http://dx.doi.org/10.1590/S1517-83822009000200034. PMid:24031379.

Bell-Sakyi L, Palomar AM, Bradford EL, Shkap V. Propagation of the Israeli vaccine strain of Anaplasma centrale in tick cell lines. Vet Microbiol 2015; 179(3-4): 270-276. http://dx.doi.org/10.1016/j.vetmic.2015.07.008. PMid:26210950.

Benesi FJ, Teixeira CMC, Leal ML, Lisboa JA, Mirandola R, Shecaira CL, et al. Leukograms of healthy Holstein calves within the first month of life. Pesq Vet Bras 2012; 32(4): 352-356. http://dx.doi.org/10.1590/ S0100-736X2012000400013.

Bianco A, Kostarelos K, Prato M. Making carbon nanotubes biocompatible and biodegradable. Chem Commun 2011; 47(37): 10182-10188. http:// dx.doi.org/10.1039/c1cc13011k. PMid:21776531.

Bouda J, Dvořák V, Minksová E, Dvořák R. The activities of GOT, gamma-GT, alkaline phosphatase in blood plasma of cows and their calves fed from buckets. Acta Vet Brno 1980; 49(3-4): 193-198. http:// dx.doi.org/10.2754/avb198049030193.

Boysen P, Storset AK. Bovine natural killer cells. Vet Immunol Immunopathol 2009; 130(3-4): 163-177. http://dx.doi.org/10.1016/j.vetimm.2009.02.017. PMid:19339058.

Bradford MM. A rapid and sensitive method for the quantitation of microgram quantities of protein utilizing the principle of proteindye binding. Anal Biochem 1976; 72(1-2): 248-254. http://dx.doi. org/10.1016/0003-2697(76)90527-3. PMid:942051.

Brown WC, Palmer GH, Lewin HA, McGuire TC. CD4+ T lymphocytes from calves immunized with Anaplasma marginale major surface protein 1 (MSP1), a heteromeric complex of MSP $1 a$ and MSP $1 b$, preferentially recognize the MSP1 1 carboxyl terminus that is conserved among strains. Infect Immun 2001; 69(11): 6853-6862. http://dx.doi.org/10.1128/ IAI.69.11.6853-6862.2001. PMid:11598059. 
Brown WC, Shkap V, Zhu D, McGuire TC, Tuo W, McElwain TF, et al. $\mathrm{CD}^{+}$T-lymphocyte and immunoglobulin G2 responses in calves immunized with Anaplasma marginale outer membranes and protected against homologous challenge. Infect Immun 1998; 66(11): 5406-5413. PMid:9784551.

Brown WC. Adaptive immunity to Anaplasma pathogens and immune dysregulation: implications for bacterial persistence. Comp Immunol Microbiol Infect Dis 2012; 35(3): 241-252. http://dx.doi.org/10.1016/j. cimid.2011.12.002. PMid:22226382.

Chen Q, Amaladoss A, Ye W, Liu M, Dummler S, Kong F, et al. Human natural killer cells control Plasmodium falciparum infection by eliminating infected red blood cells. Proc Natl Acad Sci USA 2014; 111(4): 14791484. http://dx.doi.org/10.1073/pnas.1323318111. PMid:24474774.

Contreras PA. Indicadores do metabolismo protéico utilizados nos perfis metabólicos de rebanhos. In: González FHD, Barcellos JO, Patiño HO, Ribeiro LAO, editors. Perfil metabólico em ruminantes: seu uso em nutrição e doenças nutricionais. Porto Alegre: UFRGS; 2000. p. 23-30.

Dorneles EM, Teixeira-Carvalho A, Araújo MS, Sriranganathan N, Lage AP. Immune response triggered by Brucella abortus following infection or vaccination. Vaccine 2015; 33(31): 3659-3666. http://dx.doi.org/10.1016/j. vaccine.2015.05.057. PMid:26048781.

Estes DM, Closser NM, Allen GK. IFN- $\gamma$ stimulates $\mathrm{IgG}_{2}$ production from bovine $\mathrm{B}$ cells costimulated with anti- $\mu$ and mitogen. Cell Immunol 1994; 154(1): 287-295. http://dx.doi.org/10.1006/cimm.1994.1078. PMid:8131203.

Estes DM, Hirano A, Heussler VT, Dobbelaere DAE, Browns WC. Expression and biological activities of bovine interleukin 4: effects of recombinant bovine interleukin 4 on $\mathrm{T}$ cell proliferation and $\mathrm{B}$ cell differentiation and proliferation in vitro. Cell Immunol 1995; 163(2): 268-279. http://dx.doi.org/10.1006/cimm.1995.1126. PMid:7606798.

Foldvari M, Bagonluri M. Carbon nanotubes as functional excipients for nanomedicines: II drug delivery and biocompatibility issues. Nanomedicine 2008; 4(3): 183-200. http://dx.doi.org/10.1016/j.nano.2008.04.003. PMid: 18550450

Garcia-Garcia JC, De la Fuente J, Blouin EF, Johnson TJ, Halbur T, Onet VC, et al. Differential expression of the mspla gene of Anaplasma marginale occurs in bovine erythrocytes and tick cells. Vet Microbiol 2004; 98(3-4): 261-272. http://dx.doi.org/10.1016/j.vetmic.2003.10.021. PMid: 15036535 .

GraphPad Software. QuickCalcs outlier calculator [online]. La Jolla: GraphPad; 2017 [cited 2017 March 10]. Available from: http://graphpad. com/quickcalcs/Grubbs1.cfm

Han S, Norimine J, Brayton KA, Palmer GH, Scoles GA, Brown WC. Anaplasma marginale infection with persistent high-load bacteremia induces a dysfunctional memory CD4+ T lymphocyte response but sustained high IgG titers. Clin Vaccine Immunol 2010; 17(12): 1881-1890. http:// dx.doi.org/10.1128/CVI.00257-10. PMid:20943884.

Kaneko JJ, Harvey JW, Bruss ML. Clinical biochemistry of domestic animals. 6th ed. San Diego: Elsevier Academic Press Publications; 2008.

Kocan KM, Blouin EF, Barbet AF. Anaplasmosis control: past, present, and future. Ann N Y Acad Sci 2000; 916(1): 501-509. http://dx.doi. org/10.1111/j.1749-6632.2000.tb05329.x. PMid:11193665.

Kocan KM, De la Fuente J, Blouin EF, Coetzee JF, Ewing SA. The natural history of Anaplasma marginale. Vet Parasitol 2010; 167(2-4): 95-107. http://dx.doi.org/10.1016/j.vetpar.2009.09.012. PMid:19811876.
Kocan KM, De la Fuente J, Guglielmone AA, Melendez RD. Antigens and alternatives for control of Anaplasma marginale infection in cattle. Clin Microbiol Rev 2003; 16(4): 698-712. http://dx.doi.org/10.1128/ CMR.16.4.698-712.2003. PMid:14557295.

Kurz MM, Willett LB. Carbohydrate, enzyme, and hematology dynamics in newborn calves. J Dairy Sci 1991; 74(7): 2109-2118. http://dx.doi. org/10.3168/jds.S0022-0302(91)78383-5. PMid:1680131.

Lasmar PVF, Carvalho AU, Facury-Filho EJ, Bastos CV, Ribeiro MFB. Evaluating the effectiveness of an inactivated vaccine from Anaplasma marginale derived from tick cell culture. Rev Bras Parasitol Vet 2012; 21(2): 112-117. http://dx.doi.org/10.1590/S1984-29612012000200008. PMid:22832750.

Maślanka T, Jaroszewski JJ. In vitro effects of dexamethasone on bovine CD25+ ${ }^{-} 4^{+}$and CD25- CD4 ${ }^{+}$cells. Res Vet Sci 2012; 93(3): 13671379. http://dx.doi.org/10.1016/j.rvsc.2012.01.018. PMid:22349593.

Miranda DA. Perfil metabólico e desempenho de bezerros holandeses alimentados com diferentes quantidades de sucedâneo de leite e concentrado de diferentes granulometrias [dissertation]. Minas Gerais: Universidade Federal de Minas Gerais; 2013.

Naessens J, Newson J, McHugh N, Howard CJ, Parsons K, Jones B. Characterization of a bovine leucocyte differentiation antigen of 145,000 MW restricted to B lymphocytes. Immunology 1990; 69(4): 525-530. PMid:2185984.

Noh SM, Turse JE, Brown WC, Norimine J, Palmer GH. Linkage between Anaplasma marginale outer membrane proteins enhances immunogenicity but is not required for protection from challenge. Clin Vaccine Immunol 2013; 20(5): 651-656. http://dx.doi.org/10.1128/ CVI.00600-12. PMid:23446216.

Pantarotto D, Partidos CD, Hoebeke J, Brown F, Kramer E, Briand $\mathrm{JP}$, et al. Immunization with peptide-functionalized carbon nanotubes enhances virus-specific neutralizing antibody responses. Chem Biol 2003; 10(10): 961-966. http://dx.doi.org/10.1016/j.chembiol.2003.09.011. PMid:14583262.

Rodríguez SD, García Ortiz MA, Hernández Salgado G, Santos Cerda NA, Aboytes Torres R, Cantó Alarcón GJ. Anaplasma marginale inactivated vaccine: dose titration against a homologous challenge. Comp Immunol Microbiol Infect Dis 2000; 23(4): 239-252. http://dx.doi.org/10.1016/ S0147-9571(99)00076-4. PMid:11038126.

Rosca ID, Watari F, Uo M, Akasaka T. Oxidation of multiwalled carbon nanotubes by nitric acid. Carbon 2005; 43(15): 3124-3131. http://dx.doi. org/10.1016/j.carbon.2005.06.019.

Sampaio IBM. Estatística aplicada à experimentação animal. Belo Horizonte: Fundação de Ensino e Pesquisa em Medicina Veterinária e Zootecnia; 2010.

Santos PS, Sena AA, Nascimento R, Araújo TG, Mendes MM, Martins $\mathrm{JR}$, et al. Epitope-based vaccines with the Anaplasma marginale MSP1a functional motif induce a balanced humoral and cellular immune response in mice. PLoS One 2013; 8(4): e60311. http://dx.doi.org/10.1371/ journal.pone.0060311. PMid:23579784

Silveira JAG, Rabelo EML, Lacerda ACR, Borges PAL, Tomás WM, Pellegrin AO, et al. Molecular detection and identification of hemoparasites in pampas deer (Ozotoceros bezoarticus Linnaeus, 1758) from the Pantanal Brazil. Ticks Tick Borne Dis 2013; 4(4): 341-345. http://dx.doi. org/10.1016/j.ttbdis.2013.01.008. PMid:23567028.

Silvestre BT, Rabelo ÉM, Versiani AF, Fonseca FG, Silveira JA, Bueno $\mathrm{LL}$, et al. Evaluation of humoral and cellular immune response of BALB/c mice immunized with a recombinant fragment of MSP $1 a$ from Anaplasma 
marginale using carbon nanotubes as a carrier molecule. Vaccine 2014; 32(19): 2160-2166. http://dx.doi.org/10.1016/j.vaccine.2014.02.062. PMid:24606864.

Storset AK, Kulberg S, Berg I, Boysen P, Hope JC, Dissen E. NKp46 defines a subset of bovine leukocytes with natural killer cell characteristics. Eur J Immunol 2004; 34(3): 669-676. http://dx.doi.org/10.1002/ eji.200324504. PMid:14991596.

Turse JE, Scoles GA, Deringer JR, Fry LM, Brown WC. ImmunizationInduced Anaplasma marginale-specific T-lymphocyte responses impaired by $A$. marginale infection are restored after eliminating infection with tetracycline. Clin Vaccine Immunol 2014; 21(9): 1369-1375. http:// dx.doi.org/10.1128/CVI.00246-14. PMid:25008904.

Walker DH, Dumler JS. The role of CD8 T lymphocytes in rickettsial infections. Semin Immunopathol 2015; 37(3): 289-299. http://dx.doi. org/10.1007/s00281-015-0480-x. PMid:25823954.
Walker DH, Olano JP, Feng HM. Critical role of cytotoxic T lymphocytes in immune clearance of rickettsial infection. Infect Immun 2001; 69(3): 1841-1846. http://dx.doi.org/10.1128/IAI.69.3.1841-1846.2001. PMid:11179362.

Yandar N, Pastorin G, Prato M, Bianco A, Patarroyo ME, Manuel Lozano J. Immunological profile of a Plasmodium vivax AMA-1 N-terminus peptidecarbon nanotube conjugate in an infected Plasmodium berghei mouse model. Vaccine 2008; 26(46): 5864-5873. http://dx.doi.org/10.1016/j. vaccine.2008.08.014. PMid:18771700.

Zeinali M, Jammalan M, Ardestani SK, Mosaveri N. Immunological and cytotoxicological characterization of tuberculin purified protein derivative (PPD) conjugated to single-walled carbon nanotubes. Immunol Lett 2009; 126(1-2): 48-53. http://dx.doi.org/10.1016/j.imlet.2009.07.012. PMid:19664657. 